\title{
Investigation of Organic Matter Content of Hungarian Oil Shale and Its Influence on Sorption of 2,4-Dichlorophenol
}

\author{
Renata Rauch ${ }^{1 *}$, Rita Foldenyi \\ 1 Research Institute of Bio-nanotechnology and Chemical Engineering, University of Pannonia, \\ H-8200 Veszprém, Egyetem utca 10., Hungary \\ 2 Soós Ernő Water Technology Research and Development Center, University of Pannonia, \\ H-8200 Veszprém, Egyetem utca 10., Hungary \\ * Corresponding author, e-mail: rauch@mukki.richem.hu
}

Received: 19 September 2019, Accepted: 20 November 2019, Published online: 17 December 2019

\begin{abstract}
It is not only Total Organic Carbon content (TOC) but also the type of Organic Matter (OM) that the sorption of organic pollutants by soils or other natural absorbents is correlated with. Therefore, the characterization of organic components in the adsorbents is very important to elucidate sorption mechanisms.

Oil shale samples were collected in Pula, Hungary. The TOC content of the investigated samples was approximately $6.8-40.1 \mathrm{~m} / \mathrm{m} \%$. The characterization of the organic matter in samples was carried out by using Scanning Electron Microscopy (SEM), elemental analysis, thermal analysis, and GC-MS technics. The results predominantly indicated the presence of a low degree of the branching of aliphatic chain components in the samples. The Humic Substances (HS) content of the samples was only 1-6 m/m \%, which could be determined after the treatment of oil shale with hydrogen peroxide.

The influence of the amount and type of organic material in oil shale samples was studied on the adsorption of 2,4-dichlorophenol (2,4-DCP) as a model contaminant. For this aim a series of batch equilibration experiments was carried out. The results show that the total organic carbon content of samples is a strong indicator of 2,4-DCP adsorption, while the HS content is an important feature controlling sorption capacity.

The study suggests that the special organic matter (kerogen) content of the oil shale plays a major role in its high adsorption capacity and in the nonlinearity of the isotherms. The HS covering the surface could decrease the sorption capacities despite the fact that though the amount of this organic material is quite low.
\end{abstract}

Keywords

oil shale, 2,4-dichlorophenol, adsorption

\section{Introduction}

Oil shale sources are located in several places of the Carpathian Basin, and especially large amounts can be found in the Hungarian mines in the Pannonian lakes system.

The shale originated 3-4 million years ago from the biomass of algae genus Botryococcus braunii, which accumulated in the volcanic craters. This fine-grained algaebased sedimentary rock contains large amounts of organic matter, clay volcanic ash, and calcium carbonate [1].

The Natural Organic Matter (NOM) of oil shale is one of the most important components in the sorption of organic pollutants that strongly influences the solubility, the fate of contaminants and their adsorption. NOM contains various functional groups such as carboxyl groups, alcoholic hydroxyl groups and phenolic hydroxyl groups [2].

The sorption by shale correlates with the total organic material content. It has been found in many studies that organic substances can increase the sorption of pollutants that depends on the type of organic matter. Therefore, the characterization of geochemically heterogeneous organic matter is very important in the explanation of the sorption mechanisms [3].

The organic material content of oil shales is about $5-50 \%$ and mainly composed of kerogen and small amount of soluble organic matter. It is finely dispersed in the macro- and micropores of the inorganic matrix [4]. 
The kerogen is an amorphous, three-dimensional polymer organic matter (Type I) which is insoluble in conventional organic solvents [5].

Shales contain a certain amount of residual Soil Organic Matter (SOM), too. The amount of SOM for Type I shales can reach max. $30 \%$ of NOM. The SOM has quite clearly influences apparent influence on the quantitative characterization and the adsorption properties of shale. The dissolved organics in an aquatic medium are able to enhance the solubility of contaminants and thereby reduce their extent of adsorption [6, 7]. They can interact with pollutants through electrostatic interactions, hydrogen bonding, charge-transfer and donor-acceptor mechanisms, van der Waals forces, ligand exchange and hydrophobic bonding, and therefore directly or indirectly affect the adsorption of organic contaminants $[8,9]$.

In the present work the study of the composition of organic material in Hungarian oil shale samples will be presented in order to understand how it can influence the sorption of 2,4-DCP as a model contaminant. Chlorophenols constitute a series of organic compounds that enter the natural environment due to industrial activities. The organochlorine compound, 2,4-DCP, is classified as priority pollutant both in USA and the European Union. It is widespread all over the environment, including soils. Because of its high toxicity, persistence, and bioaccumulation in the environment, there is a need to develop an ecological-friendly and efficient method to remove 2,4-DCP from the contaminated soil and groundwater.

\section{Materials and methods}

\subsection{Physical characterization of sorbents}

Three different oil shale samples (OS11, OS12, HOS) from Pula (Hungary) and bentonite from Egyházaskesző (Hungary) were used in order to investigate the effect of organic matter content on 2,4-DCP adsorption. The samples were first air-dried, then milled for 1 hour and sieved. The analyzed particle size fraction had a diameter $(\varnothing)$ less than $315 \mu \mathrm{m}$.

To examine the amount and effect of HS on adsorption, the oil shale HS was removed with hydrogen peroxide $(30 \% \mathrm{w} / \mathrm{w})$ solution [10], then dried and milled.

Table 1 contains the most important characteristics of oil shale samples, humus free oil shale and bentonite.

The mineralogical composition of the oil sale sample was analyzed by an X-ray diffraction spectrometer (PHILIPS PW3710 X-ray diffractometer) using $\mathrm{Cu} \mathrm{K}$ radiation at voltage $50 \mathrm{kV}$, current of $40 \mathrm{~mA}$ and the scan angle was from $2^{\circ}$ to $60^{\circ}$ at a rate of $2 \%$ min with a step interval of $0.02^{\circ}$. The crystalline phases were identified using the X'Pert Highscore Plus software. The minerals in the investigated samples are listed in Table 2.

\subsubsection{Scanning Electron Microscopy (SEM)}

A Thermo Fischer APREO SEM equipment item with an accelerating voltage of $2-25 \mathrm{kV}$ was used to study the surface and morphology of the Hungarian oil shale sample. Zoom: 10-400 000 .

\subsubsection{CHNS elemental analysis}

$1 \mathrm{~g}$ of dry oil shale sample was analyzed using a Thermo Electron CHNS 1100 Elemental Analyzer to determine its total carbon, hydrogen, nitrogen and sulphur content. The analysis was carried out by catalytic burning in oxygen (loop $5 \mathrm{~mL}$ ) at $1000{ }^{\circ} \mathrm{C}$ followed by chromatographic separation of the oxidation products (elution by helium, $130 \mathrm{~mL} / \mathrm{min}$ ) followed by thermal conductivity detection.

\subsubsection{Organic matter characterization}

The total organic carbon content (TOC) of the samples were determined by an Apollo 9000 (TEKMAR DOHRMAN) TOC Analyzer.

Table 1 Physical characterization of adsorbents

\begin{tabular}{lccccc}
\hline & OS11 & OS12 & HOS & $\begin{array}{c}\text { Humic } \\
\text { free HOS }\end{array}$ & Bentonite \\
\hline $\begin{array}{l}\text { Main fraction, \% } \\
\text { Characteristic }\end{array}$ & 83.6 & 75.9 & 80.8 & 70 & 80 \\
$\varnothing, \mu \mathrm{m}$ & $50-160$ & $60-150$ & $50-150$ & $70-150$ & $75-160$ \\
$\mathrm{pH}(1 \mathrm{~mol} / \mathrm{l} \mathrm{KCl})$ & 7.41 & 7.55 & 7.21 & 7.45 & 9.50 \\
Clay (\%) & 12.0 & 56.0 & 40.1 & 41.6 & 81 \\
Carbonate $(\%)$ & 80.0 & 12.0 & 40.6 & 40.1 & 14.0 \\
\hline
\end{tabular}

Table 2 The main mineral components of various oil shale samples

\begin{tabular}{lccccc}
\hline \multirow{2}{*}{$\begin{array}{l}\text { Main minerals } \\
(\%)\end{array}$} & OS11 & OS12 & HOS & $\begin{array}{c}\text { Humic } \\
\text { free HOS }\end{array}$ & Bentonite \\
\cline { 2 - 6 } & 1.0 & 4.0 & 7.3 & 7.4 & 7.0 \\
\hline Calcite & 3.0 & 2.0 & 1.6 & 2.0 & 5.0 \\
Quartz & 65 & 4.0 & 6.2 & 6.5 & - \\
Siderite & 2.0 & 4.0 & 2.5 & 3.5 & 7.0 \\
Dolomite & 1.0 & 4.0 & 1.8 & 2.2 & - \\
Albite & - & - & 0.6 & 1.1 & - \\
Kaolinite & 8.0 & 47.0 & 38.7 & 39.5 & 81.0 \\
Montmorillonite & 4.0 & 9.0 & 0.7 & 1.0 & - \\
Illite/Muscovite & 12.0 & - & 23 & 22.7 & - \\
Aragonite & 4.0 & 26.0 & 17.6 & 14.1 & - \\
Amorphous & & & &
\end{tabular}




\subsubsection{TG-DSC analysis}

Thermogravimetric analysis experiments were performed by a Setaram LabsysEvo TG-DSC analyzer whose temperature precision was $\pm 0.5^{\circ} \mathrm{C}$. $20 \mathrm{mg}$ of dry adsorbent was heated up from $30^{\circ} \mathrm{C}$ to $800{ }^{\circ} \mathrm{C}$ at a constant heating rate of $20{ }^{\circ} \mathrm{C} / \mathrm{min}$ in inert atmosphere $(80 \mathrm{~mL} / \mathrm{min})$. The weight changes of the sample were recorded continuously as a function of time or temperature, while TG and DTG curves were obtained.

\subsubsection{Pyrolysis-GC-MS}

The sample $(1.7 \mathrm{mg})$ was analyzed at a pyrolysis temperature of $500{ }^{\circ} \mathrm{C}$, using a Pyroprobe 2000 pyrolyzer connected to an Agilent 6890A/5973 GC-MS using electron impact ionization $(70 \mathrm{eV})$. The $\mathrm{GC}$ was equipped with a DB-1701 capillary column (30 m x $0.25 \mathrm{~mm}$ i.d., $0.25 \mathrm{~mm}$ ). Helium was used as carrier gas $(2.5 \mathrm{ml} / \mathrm{min})$. The starting temperature was $40^{\circ} \mathrm{C}(4 \mathrm{~min})$, the increasing temperature rate: $6^{\circ} \mathrm{C} / \mathrm{min}$ up to $280{ }^{\circ} \mathrm{C}$, then isothermal for $7 \mathrm{~min}$.

\subsection{Adsorption studies and analytical techniques}

Analytical grade sodium chloride, sodium dihydrogen phosphate and disodium hydrogen phosphate were obtained from Reanal Chemical Co. (Hungary). The HPLC grade solvent (acetonitrile) was provided by VWR Ltd. (Hungary). The 2,4-DCP standard reference material (>99\%) was the product of Sigma Aldrich.

The adsorption isotherms were obtained in a series of batch experiments. Static equilibrium experiments were carried out in a solution containing $0.1 \mathrm{~mol} / \mathrm{NaCl}$ and $0.01 \mathrm{~mol} / 1$ phosphate buffer of $\mathrm{pH}=7$. The equilibrium adsorption studies were conducted by contacting $65 \mathrm{~mL}$ of 2,4-DCP solutions of different initial concentrations (from 0 to $100 \mathrm{mg} / \mathrm{l}$ ) with $5 \mathrm{~g}$ of the swollen adsorbent in Erlenmeyer flasks, which were shaken at a speed of $250 \mathrm{rpm}$ for 1 day. After 1 day the suspension was separated by centrifuge at $6000 \mathrm{rpm}$ for $20 \mathrm{~min}$. The 2,4-DCP in the supernatant was analyzed with the HPLC method. Blanc samples ( $0 \mathrm{mg} / 1$ 2,4-DCP) were extracts which were used also for the determination of dissolved organic carbon.

The concentration of the 2,4-DCP was determined by a MERCK LaChrom HPLC system equipped with a LiChospher 100 column filled with $5 \mathrm{~mm}$ RP-18 packing material (125 mm x $4 \mathrm{~mm}$ ) (mobile phase: $65 \%$ acetonitrile/water $(65 / 35 \mathrm{v} / \mathrm{v})$ flow rate: $0.7 \mathrm{ml} / \mathrm{min}$; UV at $218 \mathrm{~nm}$ and sample size $10 \mathrm{ml})$ ).

The adsorbed amount of the solute was calculated according to the Eq. (1) [11]:
$q=V \frac{\left(c_{0}-c\right)}{m}$,

where $q$ is the specific adsorbed amount $\left(\mu \mathrm{mol} \mathrm{g} \mathrm{g}^{-1}\right), V$ is the volume of the equilibrium solution ( $\mathrm{ml}), c_{0}$ and $c$ is the initial and the equilibrium concentrations of the solute $\left(\mu \mathrm{mol} \mathrm{l}^{-1}\right)$, $m$ is the weighed amount of the dry adsorbent $(\mathrm{g})$.

\section{Results and discussion}

\subsection{Formation, properties, characterization of used adsorbents}

\subsubsection{Morphological studies}

In order to get information about the morphology of HOS, scanning electron microscopy (SEM) was applied. Images in Fig. 1 demonstrate that the sample contains well-preserved fossil colonies of Botryococcus braunii algae.

The selective preservation of the Polymer Resistant Botryococcus (PRB) plays an important role in the formation of the Hungarian oil shale, which is confirmed by its morphological properties.

The cell contents have been degraded during the first steps of sedimentation; however, the outer walls composed of PRB survived diagenesis without significant morphological alteration. These colonies containing insoluble macromolecules in their outer walls were resistant to chemical degradation and diagenetic attacks [12].

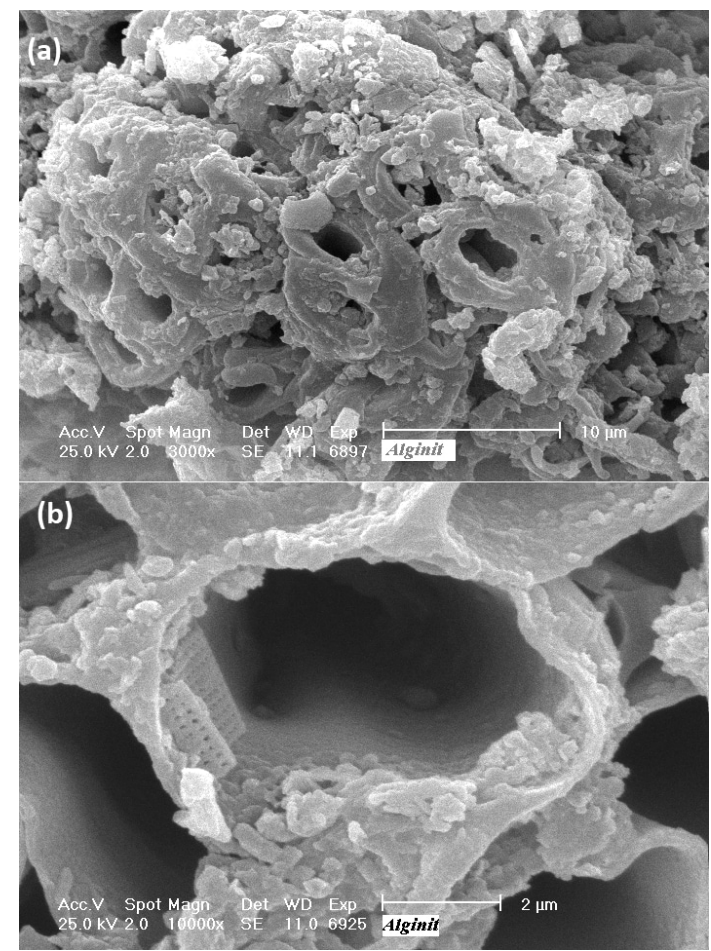

Fig. 1 Scanning electron microscopic images of the HOS. A whole colony showing the preservation of Botryococcus algae in oil shale (a) The thick layered outer walls of the colony (b). 
The colonies show cup- and chimney-shaped remnants and form a net-like structure. The fossilized alga colonies appear irregularly spherical to oval in shape, which are 3-8 $\mu \mathrm{m}$ in diameter and are open with wavy outer edges. The colony-free and chemically resistant cell walls form a pore-like structure resulting in high specific surface [13].

\subsubsection{Elemental (CHNS) analysis of the sample}

The result of the elemental analysis of the Hungarian oil shale is given in Table 3 .

The diagram made by van Krevelen can prove useful in the classification of kerogen types (Type I, II and III). Here, the ratios of the atoms of hydrogen/carbon $(\mathrm{H} / \mathrm{C})$ and oxygen/carbon $(\mathrm{O} / \mathrm{C})$ were plotted [14].

In order to classify the kerogen content of HOS, the respective data items of the sample (Table 3 ) are illustrated in Fig. 2 which demonstrates the algal origin (Type I). The higher $\mathrm{H} / \mathrm{C}$ ratio indicates the presence of immature kerogens and high oil content; therefore, it supports the hypothesis of Botryococcus origin, too. The high $\mathrm{H} / \mathrm{C}$ (1.498) and low $\mathrm{O} / \mathrm{C}(0.063)$ ratios indicate aliphatic compounds. Heteroatoms are scarce, with the $\mathrm{O} / \mathrm{C}$ ratio only 0.063 , the $\mathrm{N} / \mathrm{C}$ ratio 0.009 and the $\mathrm{S} / \mathrm{C}$ ratio 0.001 .

Table 3 Elemental analysis of HOS

\begin{tabular}{cc}
\hline elements & amount $[\%]$ \\
\hline $\mathrm{N}$ & 0.85 \\
$\mathrm{C}$ & 81.76 \\
$\mathrm{H}$ & 10.2 \\
$\mathrm{~S}$ & 0.34 \\
$\mathrm{O}($ calculated) & 6.85 \\
\hline $\mathrm{H} / \mathrm{C}$ & mol ratios \\
$\mathrm{O} / \mathrm{C}$ & 1.497 \\
$\mathrm{~N} / \mathrm{C}$ & 0.063 \\
$\mathrm{~S} / \mathrm{C}$ & 0.009 \\
\hline
\end{tabular}

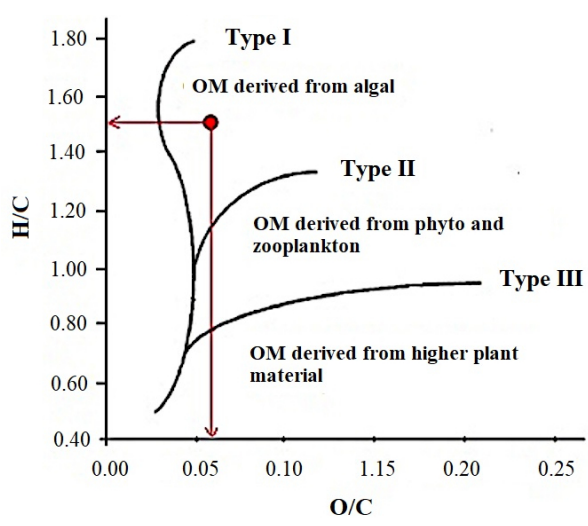

Fig. 2 Van Krevelen diagram containing the characteristics of HOS [14]

\subsubsection{Organic matter characterization, TG, dTG and DSC of Hungarian oil shale}

The results of the TG and DSC experiments for HOS under inert (He) atmosphere are shown in Figs. 3 and 4. TG and dTG show several stages in the mass loss profile. The sections are as follows: $\mathrm{T}_{1}\left(30-210^{\circ} \mathrm{C}\right), \mathrm{T}_{2}\left(210-515^{\circ} \mathrm{C}\right), \mathrm{T}_{3}$ $\left(515-617^{\circ} \mathrm{C}\right)$ and $\mathrm{T}_{4}\left(617-800{ }^{\circ} \mathrm{C}\right)$.

TG analysis of HOS showed that the sample is almost stable to $210{ }^{\circ} \mathrm{C}$. The DSC curve in Fig. 3 is characterized by an endotherm peak corresponding to water loss at temperatures below $210^{\circ} \mathrm{C}$. The weight loss to $210^{\circ} \mathrm{C}$ was $2.10 \%$, and it can mainly be attributed to water evaporation, such as that of adsorbed and interlayer water from clay minerals [15].

The combustion process begins at $210^{\circ} \mathrm{C}$ and ends over $515^{\circ} \mathrm{C}$. Between $210^{\circ} \mathrm{C}$ and $515^{\circ} \mathrm{C}$ there is an endothermic peak, which corresponds to kerogen cracking (in Fig. 4) and some mineral reactions. An important mass loss is observed in this temperature range. This stage is mainly attributed to the decomposition of bitumen and kerogen [15-17]. Under an inert atmosphere, the whole process is endothermic and the total mass loss is $27.96 \%$.

Above $515{ }^{\circ} \mathrm{C}$ the sample shows a significant weight loss after the main peak of kerogen cracking. This reaction is strongly endothermic and corresponds to mineral reactions in the oil shale under inert atmospheres. $[7,16]$. This stage is attributed to the thermal decomposition of carbonates and clay minerals. Calcite under inert atmosphere is decomposed at $700-800{ }^{\circ} \mathrm{C}$. The deep endothermic valley observed at $550-800{ }^{\circ} \mathrm{C}$ in Fig. 3 is attributed to the thermal decomposition of the dolomite. Dolomite

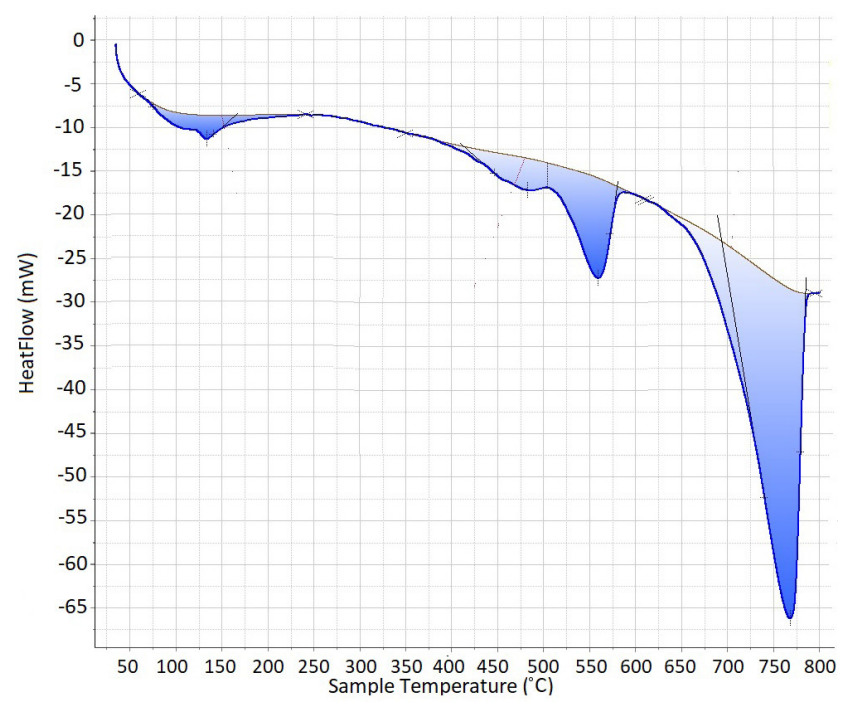

Fig. 3 DSC curve of HOS 


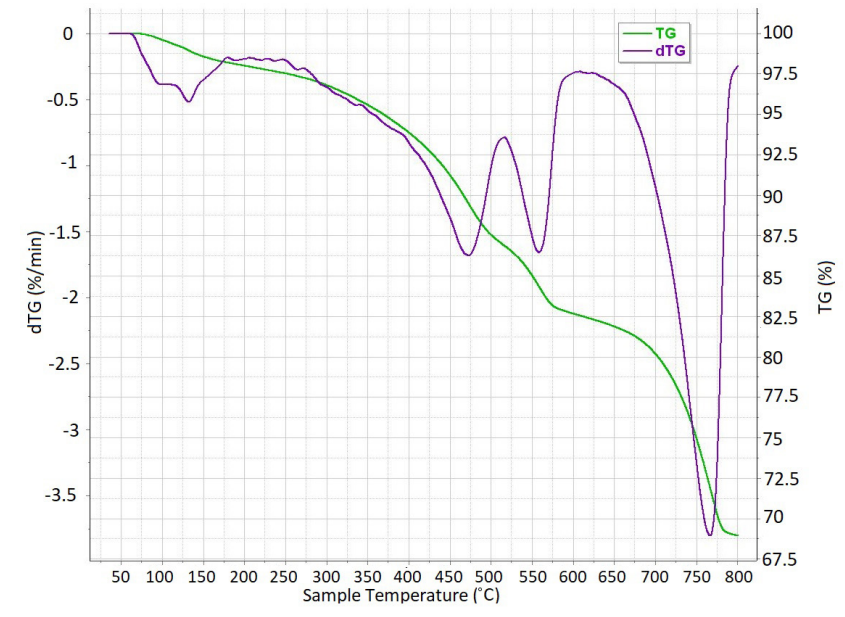

Fig. 4 TG and dTG curves of HOS

decomposition begins at $600{ }^{\circ} \mathrm{C}$ in an inert atmosphere and its structure is changed into calcite at $750{ }^{\circ} \mathrm{C}[18,19]$.

The organic material content determined by the TG analysis is $27.96 \%$, being in good correlation with the TOC value of $14.37 \%$. Their ratio is 2 , which is in accordance with the value suggested by Prybil [20] for the conversion of soil organic carbon (SOC) into soil organic matter (SOM) content.

\subsubsection{Characterization of the sample by Py-GC-MS (kerogen analysis)}

Pyrolysis GC-MS was performed with the HOS sample in order to gather more precise information about the organic matter and better insight into the building blocks of these geomacromolecules. The GC-MS chromatograms and the pyrolytic product of kerogen compounds are shown in Fig. 5. In this work, the pyrolysis temperature was set to $500{ }^{\circ} \mathrm{C}$ so that pyrolysis products mainly come from kerogen primary decomposition [21]. The optimum temperature for oil shale pyrolysis is between 500 and $520{ }^{\circ} \mathrm{C}$, because the kerogen may not be completely decomposed at lower temperatures, while high temperature can cause undesired cracking reactions [22].

The Fig. 5 shows the aliphatics are the major components. The pyrochromatogram displays a profuse homologous series of doublets corresponding to n-alkanes and n-alk-1-enes which ranges from $\mathrm{C} 8$ to $\mathrm{C} 30$ with a good continuity of carbon number $[12,23]$. They are relatively more intense with respect to the other pyrolysis products, thus confirming their higher aliphaticity as also shown by $\mathrm{H} / \mathrm{C}$ ratios. These long alkyl chains occurring in the cell walls of microalgae build up the resistant biomacromolecules (algaenans), and are important sources of kerogens via the selective preservation pathway.

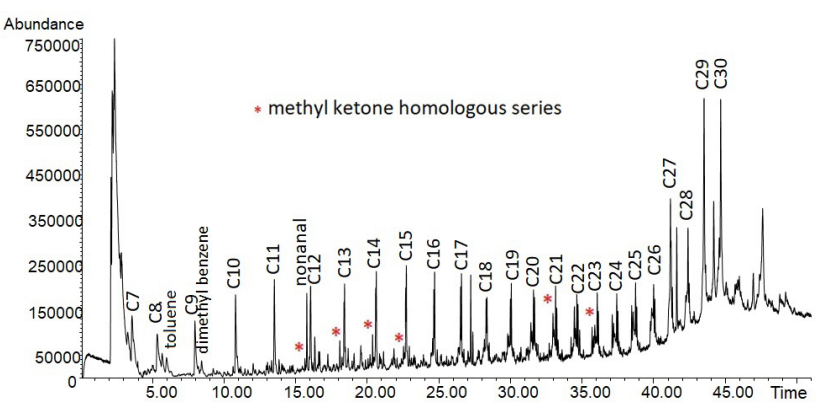

Fig. 5 Total ion chromatogram of HOS

As known from palynological studies of Hungarian oil shales, Botryococcus species contribute to organic material deposit, thus the alkyl-containing pyrolysis products are likely to be derived from Botryococcus algaenan [23].

A low amount of aromatic material, nitrogen-, oxygen-, and sulphur-containing compounds was measured, suggesting higher plant input. Aromatic hydrocarbons (benzene, toluene, phenol and dimethyl benzene) were detected only in trace amounts, indicating relatively low terrestrial input. Phenols and substituted phenols by short alkyl chains (C1-C3) in kerogen pyrolyzates are usually derived from lignin compounds and denote terrestrial origin [23].

GC/MS analysis revealed several homologous series of normal ketones. The n-alkane series and ketones are commonly observed in Type I kerogen pyrolyzates [24]. Thus, the presence of ketones in pyrolyzates is considered as evidence of the contribution of B. braunii A race strains [25].

\subsection{Adsorption studies}

The adsorption of 2,4-DCP was investigated in three oil shale samples with different organic material content, humic free HOS and bentonite which modelled the inorganic fraction of the oil shale (Table 1 and 2). The adsorbed amounts are shown as the function of the equilibrium concentration for all the adsorbents in Figs. 3 and 4. These data were fitted by the multi-step isothermal model (Eq. (2)) [11], with $\mathrm{R}^{2}$ values above 0.99 at $95 \%$ confidence level (Table 4).

$q=\sum_{i=1}^{s}\left\{\frac{q_{T i} K_{i}\left(c-b_{i}+\left|c-b_{i}\right|\right)^{n_{i}}}{2^{n_{i}}+K_{i}\left(c-b_{i}+\left|c-b_{i}\right|\right)^{n_{i}}}\right\}$,

where $c$ is the equilibrium concentration of the solution, $[\mathrm{mmol} / \mathrm{l}], \mathrm{s}$ is the number of steps of the isotherm $(i=1 \ldots \mathrm{s})$, $q_{T i}$ is the adsorption capacity, $[\mu \mathrm{mol} / \mathrm{g}], K_{i}$ is the equilibrium constant, $\left[(1 / \mu \mathrm{mol})^{n i}\right], b_{i}$ is the critical concentration limit, $[\mu \mathrm{mol} / 1], n_{i}$ is the average degree of association assigned to the $\mathrm{i}^{\text {th }}$ step of the adsorption curve. 
Table 4 Calculated parameters of Eq. (2) for the adsorption isotherms of 2,4-DCP at various $\mathrm{pH}$, at $25^{\circ} \mathrm{C}$

\begin{tabular}{lcccc}
\hline Parameters & OS 11 & OS 12 & $\begin{array}{c}\text { Humic free } \\
\text { HOS }\end{array}$ & HOS \\
\hline $\mathrm{qT} 1, \mu \mathrm{mol} / \mathrm{g}$ & 2.15 & 3.49 & 6.60 & 6.24 \\
$\mathrm{qT} 2, \mu \mathrm{mol} / \mathrm{g}$ & 6.18 & 3.30 & 2.42 & 7.60 \\
$\mathrm{~K} 1,(1 / \mu \mathrm{mol})^{\mathrm{n}}{ }_{1}$ & $3.23 \cdot 10^{-3}$ & $3.01 \cdot 10^{-3}$ & 0.02 & $2.07 \cdot 10^{-2}$ \\
$\mathrm{~K} 2,(1 / \mu \mathrm{mol})^{\mathrm{n}}{ }_{2}$ & $6.79 \cdot 10^{-3}$ & $1.23 \cdot 10^{-3}$ & 0.13 & $3.47 \cdot 10^{-2}$ \\
$\mathrm{~b} 1, \mu \mathrm{mol} / 1$ & 0.00 & 0.00 & 0.00 & 0.00 \\
$\mathrm{~b} 2, \mu \mathrm{mol} / 1$ & 162 & 63.1 & 26.2 & 38.1 \\
$\mathrm{n}_{1}$ & 1.29 & 1.27 & 1.47 & 1.01 \\
$\mathrm{n}_{2}$ & 1.16 & 1.29 & 1.34 & 1.16 \\
$\chi^{2}$ & $3.67 \cdot 10^{-2}$ & $1.41 \cdot 10^{-2}$ & $2.35 \cdot 10^{-5}$ & $6.84 \cdot 10^{-3}$ \\
$\mathrm{R}^{2}$ & 0.9927 & 0.9984 & 0.9989 & 0.9995 \\
\hline
\end{tabular}

Two-step isotherms are characteristic and indicate complex processes on and in the "adsorbent"; therefore the expression of "sorption" might be the right expression despite "adsorption". The causes are detailed below.

The TOC values were as follows: bentonite $<$ OS11 $<$ humic free $\mathrm{HOS}<\mathrm{HOS}<\mathrm{OS} 12$ (see Table 5), while the DOC was highest in the extract of humic free HOS. According to Fig. 6 it can be seen that the lower the organic matter content of the sorbent (Table 5), the lower the extent of sorption of 2,4-DCP is. Several studies have confirmed that the high organic matter content of the adsorbent significantly increases the adsorption of organic compounds [26]. The absence of organic matter (bentonite) resulted in the lowest adsorbed amount of 2,4-DCP when it was compared to the efficiency of other samples as sorbents.

The surface of bentonite is strongly hydrated in the presence of water [27]. Thus, organic pollutants cannot effectively compete with water for sorption sites on the silica surface. Therefore, 2,4-DCP is bound better by the organic matter content of the adsorbent, while clay minerals do not play an important role in sorption.

The low sorption capacity of the bentonite can be caused by the negative surface charge of bentonite. According to literature, $99.9 \%$ of 2,4-DCP is present in the deprotonated form at the $\mathrm{pH} 7(\mathrm{pKa}=7.85)$ [28]. Since this adsorbent has a high $\mathrm{pH}(9.50$, see in Table 1), the phenol hydroxyl group could dissociate and repulsion worked between its anionic form and the negative surface charge of the bentonite, resulting in the low degree of extent of sorption.

The ratio of HS increases as follows (Table 5): humic free $\operatorname{HOS}<$ bentonite $<$ OS $11<\operatorname{HOS}<$ OS12. Among the organic components, bitumen and kerogen are responsible for the relatively high solid TOC in HOS as well as in

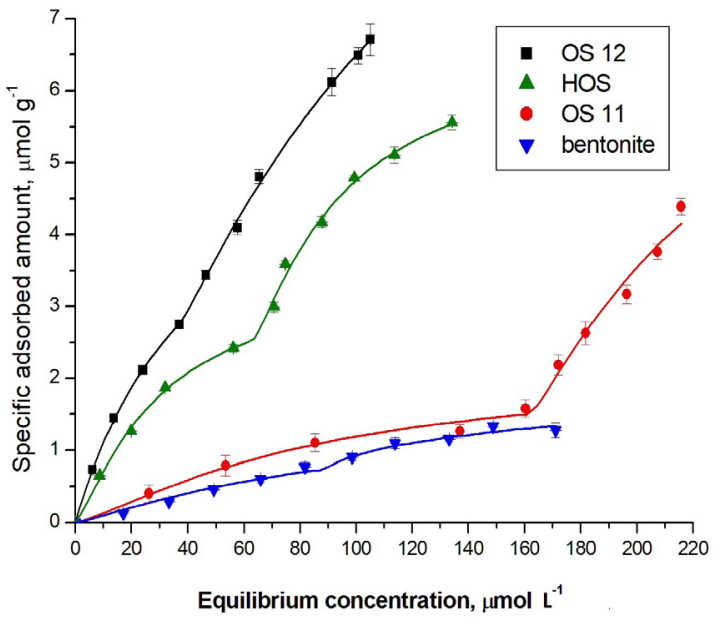

Fig. 6 Adsorption of 2,4-dichlorophenol on different adsorbents

Table 5 Carbon content of solid (TOC) samples and their extracts (DOC)

\begin{tabular}{lccccc}
\hline & OS11 & OS12 & HOS & $\begin{array}{c}\text { Humic } \\
\text { free HOS }\end{array}$ & Bentonite \\
\hline TOC (\%) & 6.85 & 40.1 & 14.4 & 10.5 & 0.09 \\
HS, (\%) & 1.08 & 6.57 & 3.81 & 0.00 & 0.05 \\
$\begin{array}{l}\text { Kerogen } \\
(\%)\end{array}$ & 5.77 & 33.5 & 10.5 & 10.5 & 0.04 \\
$\begin{array}{l}\text { DOC } \\
(\mathrm{mgC} / 1)\end{array}$ & 65.9 & 77.3 & 78.1 & 93.0 & 11.7 \\
\hline
\end{tabular}

humic free HOS. The DOC values increase in the extract of the samples as follows: bentonite $<$ OS11 $<$ OS $12<\operatorname{HOS}<$ humic free HOS.

Fig. 7 compares the adsorption isotherms of humic free HOS and HOS. It can be seen that 2,4-DCP was bound better by the humic free sample than with the HS content sample. It seems these results are in contrast with the conclusions above, although the organic content of HOS is higher (Table 5), which resulted in lower adsorbed amounts.

Since the surface is covered by HS, it is just partially accessible by contaminants like 2,4-DCP. The role of HS in the sorption of 2,4-DCP can be explained after these compounds were removed from the oil shale with hydrogen peroxide. The $\mathrm{H}_{2} \mathrm{O}_{2}$ could oxidize the HS fraction, therefore smaller molecules formed, which were more soluble, and DOC should be higher, while the kerogen and bitumen fraction remained unchanged on the surface as given in a previous study [29]. In that work the HS increased the DOC values significantly.

When HSs are present, these macromolecules can partly cover the hydrophobic surface sites and may increase the solubility of the 2,4-DCP. The enhanced solubility could be the consequence of the formation of hydrogen bonds between the HS and the model compound [30]. 


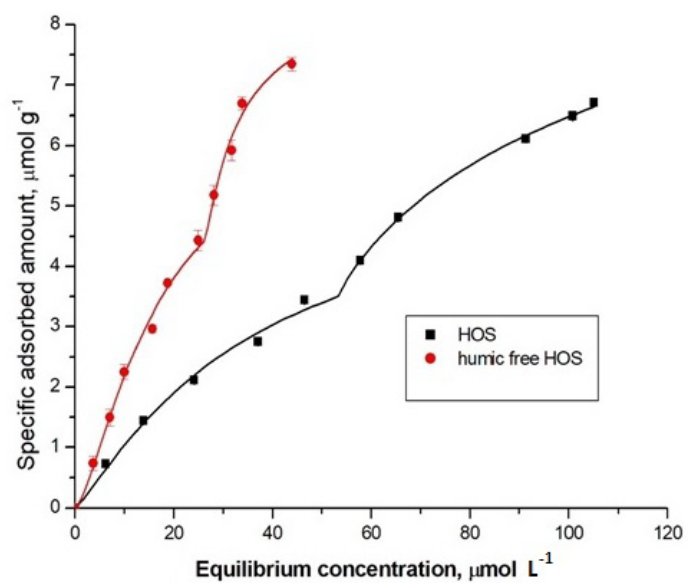

Fig. 7 Adsorption of 2,4-dichlorophenol on HOS and humic free HOS

Despite the high DOC values (Table 5) the extent of sorption is significant due to the high insoluble kerogen content of the HOS as well as that of the humic free HOS.

A lower adsorbed amount can be observed in the case of HOS than in the case of humic free HOS, which binds most of 2,4-DCP (Figs. 6 and 7). The presence of HS generally increases the solubility of organic pollutants; thus they can decrease the extent of sorption similarly to the case of untreated HOS. Since the hydrogen peroxide resulted in smaller molecules which were not able to enhance the solubility of the 2,4-DCP, the humic free HOS could bind this compound better.

The binding of 2,4-DCP by the adsorbent is principally governed by physical forces (van der Waals and hydrophobic interaction) working between this compound and the organic matter content of the samples. Therefore, it is not only on the surface that the binding process takes place (adsorption), but also within the sorbent (absorption). The high sorption capacity is explained by the

\section{References}

[1] Kulich, J., Valko, J., Obernauer, D. "Perspective of Exploitation of Alginit in Plant Nutrition", Journal of Central European Agriculture, 2(3-4), pp. 199-206, 2001. https://doi.org/10.5513/jcea.v2i3.95

[2] Bronner, G., Goss, K. U. "Sorption of Organic Chemicals to Soil Organic Matter: Influence of Soil Variability and pH Dependence", Environmental Science \& Technology, 45(4), pp. 1307-1312, 2011. https://doi.org/10.1021/es102576e

[3] Ran, Y., Xiao, B., Huang, W., Peng, P., Liu, D., Fu, J., Sheng, G. "Kerogen in Aquifer Material and Its Strong Sorption for Nonionic Organic Pollutants", Journal of Environmental Quality Abstract - Organic Compounds in the Environment, 32(5), pp. 1701-1709, 2003.

https://doi.org/10.2134/jeq2003.1701 specific surface, the large microporosity and the hydrophobic nature of the sorbent.

\section{Conclusion}

In order to study the oil shale samples (HOS), a large array of techniques was applied. Both the soluble and the insoluble fractions of the organic matter were characterized. The results of elemental analysis were performed by means of the van Krevelen diagram $(\mathrm{H} / \mathrm{C}-\mathrm{O} / \mathrm{C})$ demonstrating the algal origin of the samples collected in Pula, Hungary. Morphological investigations carried out by scanning electron microscopy proved the preservation of Botryococcus algae. The amount and the composition of the organic matter in the samples was characterized by thermal analysis as well as by pyrolysis MS. It can be concluded that aliphatic hydrocarbons are the main components. The chromatograms showed a series of n-alkanes and n-alk-1-enes (C8-C30). Smaller amounts of aromatics and low amounts of nitrogen-, oxygen-, and sulphur-containing compounds in the samples indicated that also higher plants could be recognized as the origin of organic matter. If the organic matter content of the sorbent was low, the extent of sorption of 2,4-DCP was significantly lower. It was found that the removal of the soluble humic compounds increased the adsorption capacity of the oil shale. Adsorption of 2,4DCP on different samples resulted in two-step curves. The binding mechanism of the compound was rather complex; thus it might be not only adsorption, but also absorption; therefore, the process was named simple sorption.

\section{Acknowledgement}

The activities and results of this study are part of the project GINOP-2.2.1-15-2017-00037.

[4] Cao, T., Song, Z., Luo, H., Zhou, Y., Wang, S. "Pore system characteristics of the Permian transitional shale reservoir in the Lower Yangtze Region, China", Journal of Natural Gas Geoscience, 1(5), pp. 383-395, 2016.

https://doi.org/10.1016/j.jnggs.2016.11.004

[5] Vandenbroucke, M. "Kerogen: from Types to Models of Chemical Structure", Oil \& Gas Science and Technology, 58(2) pp. 243-269, 2003.

https://doi.org/10.2516/ogst:2003016

[6] Ding, J. Y., Wu, S. C. "Partition coefficients of organochlorine pesticides on soil and on the dissolved organic matter in water", Chemosphere, 30(12), pp. 2259-2266, 1995. https://doi.org/10.1016/0045-6535(95)00099-T 
[7] Warren, N., Allan, I. J., Carter, J. E., House, W. A., Parker, A. "Pesticides and other micro-organic contaminants in freshwater sedimentary environments-a review", Applied Geochemistry, 18(2), pp. 159-194, 2003.

https://doi.org/10.1016/S0883-2927(02)00159-2

[8] Tong, Y., McNamara, P. J., Mayer, B. K. "Adsorption of organic micropollutants onto biochar: a review of relevant kinetics, mechanisms and equilibrium", Environmental Science: Water Research \& Technology, 5, pp. 821-838, 2019.

https://doi.org/10.1039/C8EW00938D

[9] Sophia A. C.,Lima, E. C. "Removal of emerging contaminants from the environment by adsorption", Ecotoxicology and Environmental Safety, 150, pp. 1-17, 2017.

https://doi.org/10.1016/j.ecoenv.2017.12.026

[10] Kézdi, Á. "Talajmechanika" (Soil Mechanics Manual), Tankönyvkiadó, Budapest, Hungary, 1976. (in Hungarian)

[11] Czinkota, I., Földényi, R., Lengyel, Z., Marton, A. "Adsorption of propisochlor on soils and soil components equation for multi-step isotherms", Chemosphere, 48(7) pp. 725-731, 2002. https://doi.org/10.1016/S0045-6535(02)00139-X

[12] Derenne, S., Largeau, C., Hetényi, M., Brukner-Wein, A., Connan, J., Lugardon, B. "Chemical structure of the organic matter in a Pliocene maar-type shale: Implicated Botryococcus race strains and formation pathways", Geochimica et Cosmochimica Acta, 61(9), pp. 1879-1889, 1997. https://doi.org/10.1016/S0016-7037(97)00042-2

[13] Kumar, M., Monga, P., Shukla, A., Mehrotra, R. C. "Botryococcus from the early Eocene lignite mines of western India: inferences on morphology, taphonomy and palaeoenvironment", Palynology, 41(4), pp. 462-471, 2017. https://doi.org/10.1080/01916122.2016.1259667

[14] Tissot, B. P., Welte, D. H. "Petroleum Formation and Occurrence", Springer-Verlag, Berlin, Germany, 1984. https://doi.org/10.1007/978-3-642-87813-8

[15] Borrego, A. G., Prado, J. G., Fuente, E., Guillen, M. D., Blanco, C. G. "Pyrolytic behaviour of Spanish oil shales and their kerogens", Journal of Analytical and Applied Pyrolysis, 56(1), pp. 1-21, 2000. https://doi.org/10.1016/S0165-2370(99)00092-3

[16] Espitalié, J., Senga Makadi, K., Trichet, J. "Role of mineral matrix during kerogen pyrolysis", Organic Geochemistry, 6, pp. 365-382, 1984. https://doi.org/10.1016/0146-6380(84)90059-7

[17] Vučelić, D., Marković, V., Vučelić, V., Spiridonović, D., Jovančićević, B., Vitorović, D. "Investigation of catalytic effects of indigenous minerals in the pyrolysis of Aleksinac oil shale organic matter", Organic Geochemistry, 19(4-6), 445-453, 1992. https://doi.org/10.1016/0146-6380(92)90011-L

[18] Sun, Y., Bai, F., Liu, B., Liu, Y., Guo, M., Guo, W., Wang, Q., Lü, X., Yang, F., Yang, Y. "Characterization of the oil shale products derived via topochemical reaction method", Fuel, 115, pp. 338-346, 2014. https://doi.org/10.1016/j.fuel.2013.07.029

[19] Gunasekaran, S., Anbalagan, G. "Thermal decomposition of natural dolomite", Bulletin of Materials Science, 30(4), pp. 339-344, 2007.

https://doi.org/10.1007/s12034-007-0056-z
[20] Pribyl, D. W. "A critical review of the conventional SOC to SOM conversion factor", Geoderma, 156(3-4), pp. 75-83, 2010. https://doi.org/10.1016/j.geoderma.2010.02.003

[21] You, Y., Han, X., Liu, J., Jiang, X. "Structural characteristics and pyrolysis behaviors of huadian oil shale kerogens using solid-state ${ }^{13} \mathrm{C}$ NMR, Py-GCMS and TG", Journal of Thermal Analysis and Calorimetry, 131(2), pp. 1845-1855, 2018. https://doi.org/10.1007/s10973-017-6667-8

[22] Wang, S., Jiang, X., Han, X., Tong, J. "Effect of retorting temperature on product yield and characteristics of non-condensable gases and shale oil obtained by retorting Huadian oil shales", Fuel Processing Technology, 121, pp. 9-15, 2014. https://doi.org/10.1016/j.fuproc.2014.01.005

[23] Derenne, S., Largeau, C., Brukner-Wein, A., Hetenyi, M., Bardoux, G., Mariotti, A. "Origin of variations in organic matter abundance and composition in a lithologically homogeneous maar-type oil shale deposit (Gérce, Pliocene, Hungary)", Organic Geochemistry, 31(9), pp. 787-798, 2000. https://doi.org/10.1016/S0146-6380(00)00093-0

[24] Van de Meent, D., Brown, S. C., Philp, R. P., Simoneit, B. R. T. "Pyrolysis-high resolution gas chromatography and pyrolysis gas chromatography - mass spectrometry of kerogens and kerogen precursors", Geochimica et Cosmochimica Acta, 44(7) pp. 9991013, 1980 https://doi.org/10.1016/0016-7037(80)90288-4

[25] Metzger, P., Largeau, C., Casadevall, E. "Lipids and Macromolecular Lipids of the Hydrocarbon-rich Microalga Botryococcus braunii. Chemical Structure and Biosynthesis. Geochemical and Biotechnological Importance", In: Herz W., Kirby, G.W., Steglich, W., Tamm, C. (eds.) Fortschritte der Chemie organischer Naturstoffe/Progress in the Chemistry of Organic Natural Products. Fortschritte der Chemie organischer Naturstoffe/ Progress in the Chemistry of Organic Natural Products, Springer, Vienna, Austria, 1991, pp. 1-70. https://doi.org/10.1007/978-3-7091-9119-4_1

[26] Sadegh-Zadeh, F., Abd Wahid, S., Jalili, B. "Sorption, degradation and leaching of pesticides in soils amended with organic matter: A review", Advances in Environmental Technology, 3(2), pp. 119132, 2017. https://doi.org/10.22104/AET.2017.1740.1100

[27] Yuan, G. D., Theng, B. K. G., Churchman, G. J., Gates, W. P. "Chapter 5.1 - Clays and Clay Minerals for Pollution Control", Developments in Clay Science, 5, pp. 587-644, 2013. https://doi.org/10.1016/B978-0-08-098259-5.00021-4

[28] PubChem,U.S.National Library of Medicine "2,4-Dichlorophenol", [online] Available at: https://pubchem.ncbi.nlm.nih.gov/compound/2_4-Dichlorophenol [Accessed: 17 September 2019]

[29] Szabó, L. P. "Characterization of alginite humic acid content", Desalination, 163(1-3), pp. 85-91, 2004.

https://doi.org/10.1016/S0011-9164(04)90180-4

[30] Foldenyi, R., Ertli, T., Mód, R. "The Fate of the Herbicides Prometryn and Metolachlor in the Soil/Soil Solution System" Central European Journal of Occupational and Environmental Medicine, 8(2-3), pp. 75-82, 2002. 